\title{
Anglican Apology of the Ancien Regime in England
}

\author{
V. N. Baryshnikov, V.N.Borisenko, M.S. Stetckevich
}

For citation: Baryshnikov V.N., Borisenko V.N., Stetckevich M.S. Anglican Apology of the Ancien Regime in England. Vestnik of Saint Petersburg University. History, 2019, vol. 64, iss. 4, pp. 1338-1354. https://doi.org/10.21638/11701/spbu02.2019.411

Following J. Clark, many scholars now use the term "ancien regime" ("old order") in relation to England of "the long $18^{\text {th }}$ century" (1689-1832). The article deals with the question of the forms and methods of the apology of the ancien regime in England by the clergy of the Established Church, which was one of its most important pillars. Focusing on the four final decades of the "long $18^{\text {th }}$ century", the authors come to the conclusion that the defense of the unequal order of society as God-given, preaching obedience and submission to state power were considered by the Church of England as one of its most important functions. At the end of the $18^{\text {th }}$ century such position was quite consistent with the prevailing public sentiment determined by the fear of the possibility of repetition of the events of the French Revolution in England. At the beginning of the $19^{\text {th }}$ century, the Anglican apology of the old order already received less support. During the struggle for the Parliamentary reform (1830-1832), the position of the Anglican Church caused an unprecedented wave of anticlericalism. At the same time, the number of supporters of the reforms among clergy, as well as among those who tried to revive the Church of England as a sacral institution (Oxford movement), increased significantly. In Victorian era, with the fading of the ancien regime, the clergy gradually ceased to consider the function of its protection a priority, and concentrated on the implementation of internal church reforms.

Vladimir N. Baryshnikov — Doctor in History, Professor, St. Petersburg State University, 7-9, Universitetskaya nab., St. Petersburg, 199034, Russian Federation; v.baryshnikov@spbu.ru

Victor N. Borisenko - PhD in History, Associate Professor, St. Petersburg State University, 7-9, Universitetskaya nab., St. Petersburg, 199034, Russian Federation; v.borisenko@spbu.ru

Mikhail S. Stetckevich - PhD in History, Associate Professor, St. Petersburg State University, 7-9, Universitetskaya nab., St. Petersburg, 199034, Russian Federation; m.steckevich@spbu.ru

Владимир Николаевич Барышников - д-р ист. наук, проф., Санкт-Петербургский государственный университет, Российская Федерация, 199034, Санкт-Петербург, Университетская наб., 7-9; v.baryshnikov@spbu.ru

Виктор Николаевич Борисенко - канд. ист. наук, доцент, Санкт-Петербургский государственный университет, Российская Федерация, 199034, Санкт-Петербург, Университетская наб., 7-9; v.borisenko@spbu.ru

Михаил Станиславович Стецкевич - канд. ист. наук, доцент, Санкт-Петербургский государственный университет, Российская Федерация, 199034, Санкт-Петербург, Университетская наб., 7-9; m.steckevich@spbu.ru

This article was supported by the Russian Foundation for Basic Research (RFBR), project No. 18-01100241 "From Erastianism to Tractarianism: the Church of England in the late $18^{\text {th }}-$ first half of the $19^{\text {th }}$ century".

Публикация подготовлена в рамках получившего финансовую поддержку РФФИ (отделение гуманитарных и общественных наук) научного проекта № 18-011-00241 “От эрастианизма к трактарианизму: Церковь Англии в конце XVIII - первой половине XIX в."

(c) Санкт-Петербургский государственный университет, 2019 
Keywords: ancien regime, Anglicanism, anticlericalism, Church of England, French Revolution, H. More, social subordination.

\section{Англиканская апология старого порядка в Англии}

\section{В. Н. Барыиников, В. Н. Борисенко, М. С. Стеикевич}

Для цитирования: Baryshnikov V. N., Borisenko V.N., Stetckevich M. S. Anglican Apology of the Ancien Regime in England // Вестник Санкт-Петербургского университета. История. 2019. Т.64. Вып. 4. С. 1338-1354. https://doi.org/10.21638/11701/spbu02.2019.411

В настоящее время в историографии прочно утвердилось понятие «долгий XVIII век», используемое для характеристики временного отрезка английской истории, верхней хронологической границей которого является Славная революция 1688-1689 гг. а нижней - парламентская реформа 1832 г. Вслед за Дж. Кларком многие исследователи допускают использование термина «старый порядок» (ancien regime) применительно к Англии данного периода, естественно, не отождествляя его с классическим французским вариантом. В статье рассматривается вопрос о формах и методах апологии старого порядка духовенством Церкви Англии, являвшейся одной из его главаных опор. Важнейшими источниками являются епископские послания и парламентские выступления, проповеди и памфлеты, написанные англиканскими священниками. Сосредоточивая внимание на четырех завершающих десятилетиях «долгого XVIII века», авторы приходят к выводу о том, что защита существующего порядка как богоустановленного, незыблемости иерархического устройства и необходимости подчинения власти рассматривались Церковью Англии в качестве одной из ее важнейших функций. В конце XVIII в. такая позиция вполне соответствовала преобладавшим общественным настроениям, определявшимся страхом перед возможностью повторения в стране событий Французской революции. В период активизации радикального движения во второй половине 1810-х гг. англиканская апология старого порядка пользовалась уже меньшей поддержкой. В борьбе за первую парламентскую реформу (1830-1832 гг.) позиция Церкви Англии вызвала небывалую волну антиклерикальных выступлений. В то же время в среде духовенства значительно увеличилось, по сравнению с концом XVIII - началом XIX в., число сторонников реформ, а также тех, кто считал важнейшим возрождение Церкви Англии в качестве сакрального института (Оксфордское движение). В Викторианскую эпоху по мере ухода в прошлое самого старого порядка функция его защиты постепенно перестала рассматриваться духовенством, сосредоточившимся на осуществлении внутрицерковных реформ, в качестве приоритетной.

Ключевые слова: старый порядок, англиканизм, антиклерикализм, Церковь Англии, Французская революция, Х. Мор, социальная субординация.

Following the outstanding historians F. Braudel and E. Hobsbawm, who, seeking to identify more clearly a period of historical development extending beyond the calendar century, used the term "the long $16^{\text {th }}$ century" and "the long $19^{\text {th }}$ century", modern researchers increasingly use the term "the long $18^{\text {th }}$ century" . This notion refers to the time period of English history, the starting point of which is usually considered the Glorious Revolution of 1688-1689, and the final point - the Parliamentary reform of 1832 . How-

${ }^{1}$ See, for example: Jacob W. M. The Clerical Profession in the Long Eighteenth Century, 1680-1840. Oxford, 2007; O'Gorman F. The Long Eighteenth Century: British Political and Social History 1688-1832. London, 2016. 
ever, actively using the term itself, researchers are far from agreement about the assessment of the role of the long $18^{\text {th }}$ century in British history. The judgment, expressed in 1981 by M. Rosen, that in the $18^{\text {th }}$ century "The English bourgeoisie secured its political hegemony" and "generated the first successful capitalist state in world history", in the light of modern historiographic trends looks like an anachronism. Already in the 1970s, B. Hilton convincingly showed that even Lord Liverpool's administration (1812-1827) for a long time considered the defense of "landed interest" rather than support of industrial development the main political goal ${ }^{3}$. G. Kitson Clark and J. Cookson actively used the term "the old order" in their research, moreover, the former extended the time frame of the period up to the middle of the $19^{\text {th }}$ century ${ }^{4}$. But the most decisive blow to the notions of the long $18^{\text {th }}$ century as an era of bourgeois progress and industrialization became the voluminous work of J. Clark published in $1985^{5}$. This book was later released in a second, extended edition ${ }^{6}$.

Clark's concept sparked such a lively controversy that, as noted by J. Black, no two scholars on eighteenth-century Britain can meet anywhere in the world without discussing his works ${ }^{7}$. The main idea of Clark is such: the English society of the long $18^{\text {th }}$ century was "Anglican, aristocratic and monarchical. Gentlemen, the Church of England and the Crown commanded an intellectual and social hegemony" ${ }^{8}$. In English culture, standards of a rural society dominated, hierarchy and paternalism remained, industrialization did not reach serious scale 9 . By using the term "confessional state", Clark understands it not just as the status of the Church of England, but as the dominance of idea that religion should be the basis of society and the legislative process ${ }^{10}$. Clark's concept was initially harshly criticized $^{11}$, but after a certain time, it turned out that many researchers, rejecting some extremes of Clark's concept (especially the thesis that the fall of the old order in 1832 was caused not by its internal erosion but rather by a coincidence of political circumstances) agreed with the possibility of using the term "ancien regime" in relation to the long $18^{\text {th }}$ century in Britain, naturally, without identifying it with the classic French version ${ }^{12}$.

In this regard, it seems quite appropriate to talk about the English model or version of the ancien regime. Noting its specific features, it is necessary to emphasize the softness of the "confessional state", which provided Roman Catholics and dissenters with freedom

${ }^{2}$ Rosen M. The Dictatorship of the Bourgeoisie: England, 1688-1721 // Science \& Society. 1981. Vol. 45, No. 1. P. 25, 27.

${ }^{3}$ Hilton B. Corn, Cash, Commerce: Economic Policies of the Tory Governments, 1815-30. Oxford, 1980.

${ }^{4}$ Kitson Clark G. Churchmen and Condition of England, 1832-1885. The Old Regime to the Modern State. London, 1973; Cookson J.E. Lord Liverpool's administration: The crucial years, 1815-1822. London, 1975. P. $12-14$.

${ }^{5}$ Clark J.C. D. English Society, 1688-1832. Ideology, Social Structure and Political Practice during the Ancien Regime. Cambridge, 1985.

${ }^{6}$ Clark J. C. D. English Society, 1660-1832: Religion, Ideology, and Politics during the Ancien Regime. Cambridge, 2000.

7 Black J. England's Ancien Regime? // History Today. 1988. Vol.38, no. 3. P. 51.

8 Clark J.C.D. English Society, $1688-1832 \ldots$... P. 7.

9 Ibid. P. 70-87.

${ }^{10}$ Clark J. C. D. English Society, 1660-1832... P.26-34.

${ }^{11}$ Innes J. Jonathan Clark, Social History and England's "Ancien Regime" // Past \& Present. 1987. No. 115. P. 165-200.

12 See, for example: Porter R. Georgian Britain: an Ancien Regime? // British Journal for Eighteenth Century Studies. 1992. Vol. 15. P. 141-144; O’Gorman F. The Long Eighteenth Century... P. 180-182. 
of worship; the vagueness of the very concept of "aristocracy" since it included not only title-holders but also a significant part of landowners. The circumstance on which G. Kitson Clark focused attention also seems essential: the wide distribution of "the concept that an unequal order of society had been established by God"13.

One of the most important pillars of the ancien regime was the Church of England, which had the status of "by Law Established" and was often referred to simply as "The Establishment" by contemporaries. In the House of Lords, there were 2 archbishops and 24 bishops. If we consider that for most of the $18^{\text {th }}$ century the number of members of the upper House slightly exceeded 200, the voices of the prelates meant quite a lot. Appointments to episcopal posts were often political, with the origin and protection being the most crucial priorities. According to N. Ravitch and R. A. Soloway, at the turn of the $18^{\text {th }}$ and $19^{\text {th }}$ centuries, the overwhelming majority of the prelates were associated with land elite by origin and/or family ties ${ }^{14}$.

The number of ordinary clergy was 15 000-18 000. A clear division into parties, a fierce controversy between them will begin later, in the 1830s. In the last decades of the long $18^{\text {th }}$ century, the differences between the largest group - the "Orthodox" (using the terminology of N. Murray), which did not have a clear theological views, and regarded the Church of England primarily as the Establishment ${ }^{15}$; High Church (which emphasized the importance of tradition, including the pre-Reformational), Evangelicals (who did not attach great importance to tradition) and Latitudinarians (who offered very broad version of Christianity) were, in comparison with the subsequent period, rather blurred.

Almost all priests were graduates of Oxford or Cambridge Universities, and, possessing by 1830 an average income of $£ 275$ a year ${ }^{16}$, not only belonged to the gentlemen but only slightly differed, including their way of life, from landed gentry ${ }^{17}$. From the end of the $18^{\text {th }}$ century, there had been a significant increase in the number of priests who performed the functions of justices of peace, who exercised judicial authority and functions of local self-government in the counties. By the early 1830 s, priests had already constituted $20-$ $30 \%$ of the corps of justices of the peace, and in some counties this figure exceeded $40 \%{ }^{18}$. Very often clergymen were known to the local population precisely in this capacity, and not as pastors. It is significant that the priests were assigned the function to read government proclamations in parish churches ${ }^{19}$. All these circumstances made both the higher and lower Anglican clergy obvious defenders of the ancien regime.

The theme of the ancien regime's apology by the Anglican clergy is not overlooked by researchers. First of all, we should mention the works of such scholars as G. Best, G. Kit-

13 Kitson Clark G. Churchmen and Condition of England... P.9.

${ }^{14}$ Ravitch N. The Social Origins of the French and English Bishops in the Eighteenth Century // The Historical Journal. 1965. Vol.8, no.3. P.319-320; Soloway R.A. Prelates and People. Ecclesiastical Social Thought in England, 1783-1852. London, 1969. P. 7-8.

${ }_{15}$ Murray N. U. The Influence of the French Revolution on the Church of England and its Rivals. PhD. Thesis. Oxford, 1975. P. 4-9.

16 Jacob W. M. The Clerical Profession in the Long Eighteenth Century... P. 143.

17 Russell A. The Clerical Profession. London, 1989. P.33-35.

18 Evans E. J. Some Reasons for the Growth of English Rural Anti-clericalism // Past \& Present. 1975. No.66. P. 103-104; Gilbert A.D. Religion and Society in Industrial England: Church, Chapel and Social Change, 1740-1914. London, 1976. P. 133.

19 Jacob W. M. The Clerical Profession in the Long Eighteenth Century... P. 301. 
son Clark, R. A. Soloway and R. Hole ${ }^{20}$. J. Clark also paid considerable attention to the examination of this issue ${ }^{21}$. However, the subject does not seem to have been exhausted. The aforementioned authors either focused their attention on the entire long $18^{\text {th }}$ century (R. Hole, J. Clark), or included in their research a large part of the Victorian era (R. A. Soloway, G. Kitson Clark). Meanwhile, in the history of the long $18^{\text {th }}$ century there should be distinguished a period covering its past four decades when the apology of the ancien régime was the most intense. Within it, we can identify three peak periods.

The first period was the epoch of the French Revolution and the Revolutionary Wars (especially 1789-1793), the second - the time of intensive radical agitation in favor of Parliamentary reform (1816-1819), and finally, the third - the struggle for the first Parliamentary reform (1830-1832). Although many arguments, references to certain texts of Holy Scripture, and final conclusions were often repeated, each period had its own specifics. The main goal of this article is to analyze texts (first of all, sermons and episcopal charges), which were released by the Anglican clergy, in order to identify both the core aspects and the peculiarities of the apology of the ancien regime during each of the abovementioned critical periods of the final part of the long $18^{\text {th }}$ century.

The fact of the enormous influence of the French Revolution of the late $18^{\text {th }}$ century on the ideological, political, economic and religious development of England is generally recognized ${ }^{22}$. Contemporaries also did not doubt the reality of the serious impact of the French events on the situation in England. A Whig politician, lawyer and litterateur H. Cockburn (1779-1854) recalled that "the Revolution in France... was, or was made, the all in all. Every thing, not this or that thing, but literally every thing was soaked in this one event"23. If English public opinion initially was rather positive about events in France, including dissenting pastors and even some Catholic priests ${ }^{24}$, the position of the clergy of the Established Church was different. Only liberally-minded bishop R. Watson expressed the hope that, as a result of the Revolution, "the despotism which yet subsists in Europe other nations will soon be everywhere changed into a lawful rule and right supremacy" 25 .

Already in the first public judgments of the Anglican clergy about the French Revolution, one can find assessments that subsequently will be repeated many times, and also a search for possible barriers to the transfer of the French experience to England. In the sermon preached by W. Jones (October 20, 1789), a clear distinction is made between "the power of government" and "the power of the people". Only the first is "ordained of God" and "the gift of God to nation that serveth him", while the second "is his curse upon the disobedient who are departed from him" 26 . It is the second form of power that is being established in France now, but it can only lead to the assertion of tyranny in its worst

20 Best G.F.A. Temporal Pillars. Queen Anne's Bounty, the Ecclesiastical Commissioners and the Church of England. Cambridge, 1964. P. 137-171; Kitson Clark G. Churchmen and Condition of England... P.24-226; Soloway R.A. Prelates and People...P.19-348; Hole R. Pulpits, Politics and Public Order in England, 1760-1832. Cambridge, 1989.

${ }^{21}$ Clark J. C. D. English Society, 1660-1832... P. 256-317.

22 The most important contemporary research works were analyzed in the historiographical essay by E. MacLeod. See: MacLeod E. British Attitudes to the French Revolution // The Historical Journal. 2007. Vol.50. P. 689-709.

${ }^{23}$ Cockburn H. Memorials of His Time. New York, 1856. P. 82.

${ }^{24}$ Hole R. Pulpits, Politics and Public Order in England... P. 99.

25 Watson R. Miscellaneous Tracts on Religious, Political and Agricultural Subjects. Vol.2. London, 1815. P. 150.

${ }^{26}$ Jones W. Sermons: Practical, Doctrinal and Expository. London, 1829. P. 163. 
form ${ }^{27}$. Jones stresses: "the Gospel knows of no such government as a commonwealth. In the New Testament kings as supreme and those who were sent by kings... are pointed out as the proper objects of civil obedience" 28 . Therefore, the most important task of the clergy in the present conditions ("times... are bad and daily altering for the worse") Jones sees in the following: "we should endeavour to make the people aware of and admonish them still to pray for kings and all that are in authority as Christians did of old and as the Church of England directs us to do now"29.

Dean of Canterbury G. Horne defended the idea of submission in equally definite expressions. In his sermon, also preached in October 1789, he stressed that it doesn't matter whether the government was chosen by the people or not: "the law of God enjoins obedience to every government settled according to the constitution of the country in which it subsists" 30 . Therefore, "although government may sometimes be bad, rebellion generally be worse"31.

Undoubtedly, the theme of the necessity of submission to power was not new, and such sermons had been read before. But in the considerable part of the $18^{\text {th }}$ century, the Anglican clergy, emphasizing the God-given nature of state power, at the same time mentioned the possibility of correcting some of its forms, which enabled to give a satisfactory explanation of the events of the Glorious Revolution. Now the accents were placed differently. The focus was on the inadmissibility of any attempts to reform the government, the divinity of the monarchial form of government and the condemnation of republicanism.

The sermon of C. Bayley is quite indicative. Constant teaching of submission to existing power is characterized by him as the "duty of every Christian pastor"32. Recognizing the existence of exceptional cases that make obedience impossible, Bayley simultaneously notes: "if there be danger of tying too hard the knot of allegiance to the Sovereign, there is far greater danger of making it too loose" ${ }^{33}$. The preacher calls the flock to dread "innovations either in religion or civil government" 34 , and "meddle not with those who are given to change, nor with their publications" 35 .

In a sermon preached in the House of Lords on January 30, 1793 ( the day of the execution of Charles I (1649) and nine days after the guillotine of Louis XVI), Bishop of St. David's S. Horsley focused on criticizing the contractual ideas of people's sovereignty. That was the prevailing false notion that "Kings are the Servants of the People"36, which led both monarchs to death, and their countries - to adversity, from which England in the $17^{\text {th }}$ century managed to happily quit ${ }^{37}$. Now "our Constitution exempts her Kings from the degrading necessity of being accountable to the Subject" ${ }^{\prime 3}$. The situation in France

\footnotetext{
27 Ibid. P. 167-168.

28 Ibid. P. 169.

29 Ibid. P. 171.

30 The Works of the Right Reverend George Horne. Vol. 3. London, 1818. P. 387.

31 Ibid. P. 392.

32 Bayley C. Religion and Loyalty inseparable. Manchester, [S.n.], 1792. P. 6.

33 Ibid. P. 9.

34 Ibid. P. 6.

35 Ibid. P. 22.

36 Horsley S. A Sermon Preached before the Lords Spiritual and Temporal on January 30, 1793.

37 Ibid. P. 20-26.

38 Ibid. P. 20-21.
} London, 1793.P. 19. 
was characterized by him in such a manner: "Her Government demolished! Her Altars overthrown! ... Atheists directing her councils!"39

The assessment of the French Revolution as "godless", often expressed in a ratherfervent manner, was commonplace in the speeches of both prelates and rank-and-file clergy. S. Horsley was especially active stressing that in France "atheistical conspiracy" was not aimed at overthrowing "corruptions" of the Roman Catholic Church, but at destroying "every thing that is good, amiable, and holy in Christianity" 40.

Naturally, the overwhelming majority of the Anglican clergy evaluated the war with France as just war. Thus, Bishop of Norwich C. Manners-Sutton, without denying that war is evil in principle, at the same time noted the fundamental difference between the current and previous conflicts with France. Now the war is waged against infidelity per se. Defining the French as "Heathen nation" ${ }^{1}$, Bishop summarized: "it is the defence of our homes and families, of our laws, our liberty, and above all our religion" ${ }^{42}$. In conclusion, he expressed the hope that God would bestow "nerve and strength to our arms and wisdom and to our counsels" ${ }^{\prime 3}$. In the instructions addressed to the clergy, the struggle with the French was characterized as "just and necessary war" waged with the goal of "maintenance of every Ordinance, Divine and Human, essential to the well-being of Man"44.

The apology of the old order included also the exposure of the internal enemy. Traditional anti-Catholic phobias temporarily weakened, and now dissenters (nonconformists) began to appear as the main force that threatened the established order. Interestingly, anti-dissenters' phobias, large-scale at the beginning of the century (The Sacheverell riots, 1710), gradually subsided, and a growing number of votes were given in Parliament for the repeal of the Test and Corporation Acts - the most important statutes taken at the end of the $17^{\text {th }}$ century that restricted the rights of nonconformists. However, in 1790, another attempt of repeal suffered a crushing defeat, and the majority for the preservation of Acts amounted to almost 200 votes ${ }^{45}$.

This circumstance was due to the fact that many dissenting preachers (R.Price, J.Priestley, R. Hall) not only welcomed the French Revolution in enthusiastic expressions but also expressed the hope for reforms in England aimed at the expansion of religious freedom, political and civil rights in England. During the Parliamentary debates, the future famous author of "Reflections on the Revolution in France" E. Burke (1729-1797) delivered a lengthy speech against the repeal of Acts, in which he reproached dissenters with the intention to undermine the existing order, and above all - to deprive the Church of England of her established position ${ }^{46}$. This kind of public sentiment was fully supported by the Established Church.

${ }^{39}$ Ibid. P. 22.

40 The Charges of Samuel Horsley, Late Lord Bishop of St. Asaph, delivered at Several Visitations of the Dioceses of St. David's, Rochester and St.Asaph. Dundee, 1813. P. 136-137.

${ }^{41}$ Manners-Sutton C. A Sermon Preached on Friday, February $28^{\text {th }}$, 1794. London, 1794. P. 14.

42 Ibid. P. 20

43 Ibid. P. 20.

44 A Form of Prayer and Thanksgiving to Almighty God; to be used in all Churches and Chapels throughout England ... on Tuesday the nineteenth day of December, 1797. London, 1797. P. 6-7.

45 See: e. g.: Watts M. R. The Dissenters. From the Reformation to the French revolution. Oxford, 1978. P. $482-490$.

46 The Parliamentary History of England from the earliest period to the year 1803. Vol.28. London, 1816. P. 432-443. 
The clergy of the Church of England always viewed dissenters as schismatics, but now the attacks on them turned into a large-scale campaign. Priest E. Tatham called the dissenters "false prophets' who "under the appearance of religion" try to undermine the Church and "State which is so admirably constituted; whoever, instead of the Love of our King, of our Country and of each other, are labouring to Promote Hatred, Variance, Emulations... whoever... would introduce Sedition and Rebellion" ${ }^{47}$. The statement of the existence of a rigid connection between being outside the Church of England and political disloyalty is also characteristic of other Anglican sermons. The priest T. Bancroft asserted that it was even impossible to call non-conformist pastors "Teachers of Religion, though they wear the garb and affect the name" 48 . They were accused of borrowing French experience, pushing the country onto the disastrous path of undermining the constitutional order $^{49}$.

Anti-dissenters' sentiments received practical expression in the actions of so-called "Church and King mobs". The major riots occurred in July 1791 in Birmingham, where the main object of the attack was a famous scientist, naturalist and at the same time Unitarian minister J. Priestley, who continued to voice public approval of the ideas of the French Revolution. The Unitarian chapel, the house of Priestley and his laboratory were destroyed, and he himself was forced to flee ${ }^{50}$. The modern researcher G. Koabel, without denying the significance of political, and in some cases, socio-economic motives in the actions of the loyalist mob, at the same time points out religious reason as the most important (especially in Oxford and Cambridge riots in the winter of 1792-1793) ${ }^{51}$. He shows convincingly that the level of clerical participation in Loyalist Associations, organized in early 1790 s, was very high, and in some cases, the priests were leaders of these structures ${ }^{52}$. It is less arguable that Tatham was directly responsible for the Oxford riots, although the fact that he repeated his fiery "Sermon Suitable to the Times" four times in four different Oxford churches ${ }^{53}$ certainly deserves attention.

One of the most important directions of Anglican apology of the ancien regime was the upholding of the idea of the inviolability of the God-established social hierarchy. The idea that God gave every man, rich and poor, their proper station in society, was also not new. But under the influence of the French Revolution, it came to the fore: "the distinctions of high and low, rich and poor, are the appointments of Divine Providence" (bishop G. Pretyman- Tomline) ${ }^{54}$; "that there should be high and low rich and poor in the same society is a decree of the Almighty fixed and unifor" (warden of Winchester College and future bishop G. Huntingford) ${ }^{55}$.

Up to this point, we have quoted statements of clergymen who belonged to the "Orthodox" and High Church parties in the Church of England. In general, the Evangeli-

47 Tatham E. A Sermon Suitable for the Times. London, 1792. P. 15.

48 Bancroft T. A Sermon preached at the Cathedral church, in Chester. Manchester, 1793. P.7.

49 Ibid. P. 8-14.

50 See: e. g.: Rose R. B. The Priestley Riots of 1791 // Past and Present. 1960. No. 18. P. 68-88.

51 Koabel G. Religious loyalism: The Anglican Church and the conservative movement of 1792-3.

A Thesis for the degree of Master of Arts in History, Regina, [S. n.], 2009. P. 72-74.

${ }^{52}$ Ibid. P. 35-66.

53 Ibid. P.76-79.

${ }^{54}$ Pretyman-Tomline G. A Charge Delivered to the Clergy of the Diocese of Lincoln in May and June 1794. London, 1794. P. 21.

55 Huntingford G. Twelve Discourses on Different Subjects. London, 1795. P. 298. 
cals supported the significance of the protective functions of the Established Church, but there were certain nuances. They put forward a call to abandon formal religion in favor of sincere and genuine faith. A vivid expression of the public position of the Evangelicals was a tract "A Practical View of the Prevailing Religious Systems of Professed Christians" written by W. Wilberforce (1759-1833) - a politician who gained widespread publicity as a fighter for the abolition of the slave trade. "Christianity calls on us," Wilberforce pointed out, "not merely in general to be religious and moral, but specially to believe the doctrines, imbibe the principles, and practise the precepts of Christ" ${ }^{\text {" }}$. Touching on social aspects, Wilberforce pointed out that lower orders of society should be "diligent, humble, patient". They should be told that their "more lowly path has been allotted to them by God; that it is their part faithfully to discharge its duties, and contentedly to bear its inconveniences" 57 .

The problems of the preservation of the social hierarchy were most thoroughly touched upon in the works of an evangelical religious writer Hannah More (1745-1833). If Wilberforce addressed primarily to the English elite, the writings of More were prepared for the low classes of society. After the publication of the second part of Thomas Paine's tract "Rights of man" (1792), in which the idea of the need for representative government was developed in relation to England, Bishop of London B. Porteus turned to More. She later recalled that bishop declared "that I should repent it on my death bed, if I, who knew so much of the habits and sentiments of the lower order of people, did not write some little thing tending to open their eyes under their present wild impressions of liberty and equality" ${ }^{8}$. The first experience of this kind of writing was the pamphlet "Village Politics" (1792) written (under the pseudonym "Will Chip") in the form of a dialogue between two villagers - Jack and Tom. Jack convinces Tom that the latter's desire to achieve in England the approval of liberty, equality, rights of man and "general reform...the same as they have got in France" 59 is completely groundless since the country already possesses "a fine constitution" 60 , and on the other side of the Channel tyranny, murder and atheism are reigning ${ }^{61}$. Jack tells Tom: "Instead of indulging discontent because another is richer than I in this world... I read my Bible, go to church, and think of a treasure in heaven" 62 . The pamphlet ends with a quotation from the New Testament: "Study to be quiet, work with your own hands and mind your own business" [1 Thess. 4:11] ${ }^{63}$.

This New Testament text could be an epigraph to "Cheap Repository Tracts" (17951798). The total number of Tracts sold by March 1796 had reached 2,000,000 copies $^{64}$. Tracts consistently reveal the main idea of More: the poor should not complain about their fate, perceiving poverty as virtue, and at the same time they should work hard, not be interested in politics, diligently attend church. The hero of the most famous tract, "The Shepherd of Salisbury Plain", is sure that God "had state and condition of life at his choice,

56 Wilberforce W. A Practical View of the Prevailing Religious Systems of Professed Christians in the Higher and Middle Classes of this Country Contrasted with Real Christianity. London, 1797. P. 16.

57 Ibid. P. 405.

58 The Life of Hannah More with Selections from Her Correspondence. London, 1862. P. 174.

59 Will Chip. Village Politics. York, 1793. P.3-4.

${ }^{60}$ Ibid. P.7.

61 Ibid. P. 14-17.

62 Ibid. P. 13-14.

63 Ibid. P. 18.

${ }^{64}$ Porter R. Enlightenment. Britain and Creation of the Modern World. London, 2001. P. 468. 
and chose a hard one; while I only submit to the lot that is appointed me"65. The Bible for Shepherd is his "meat, drink, and company" 66 . As an ideal of social harmony, More expects a situation when rich and poor "Raise many a pure and holy vow // In gratitude to God"67.

Speaking about the affinity, although not a complete identity, between the positions of the "Orthodox", High Churchmen and the Evangelicals, it is worth mentioning the third, Latitudinarian, party in the Church of England. In the 1790s, it experienced a significant numerical reduction and became almost indistinguishable from the "Orthodox"68. One of the most well-known latitudinarians, archdeacon W. Paley, in 1791 addressed to the lower classes of English society with a pamphlet in which he stressed that they should not try "to covet the stations or fortunes of the rich... by force or through the medium of the public uproar" because in the present circumstances it is equivalent "to venture out to sea in a storm but to venture for nothing" ${ }^{69}$. Bishop R. Watson, priest C. Wyvill retained a commitment to the idea of reforms, including Parliamentary, although they understood their impossibility in the nearest future. Some latitudinarian priests left the Church of England and became Unitarians ${ }^{70}$.

But there were "black sheep in the family" of Anglican clergy. First of all, such figure as priest V.Knox (1752-1821) should be noted. In 1795, he prepared the voluminous tract "The Spirit of Despotism", which was published in the USA. In England it appeared privately, in a small number of copies and without the consent of the author. The central idea of the tract is that "spirit of despotism" took deep roots in England, finding expression in an attack on liberties of the people. In particular, Knox, not opposing the need for loyalty, condemns (clearly referring to the priests of the Church of England), those who "represent... loyalty as a religious duty, partaking the nature of divine worship" ${ }^{\text {"11 }}$. Knox's work ends with the following conclusion: "let parliament be reformed. This measure will... give permanency to the throne and happiness to the people. Kings will be republicans in the true sense of that term; and the spirit of despotism become the spirit of philanthropy Sermons, which made the emphasis not on the justification and justice of the war on the part of England, but on the fact that war as such is contrary to the spirit of Christianity, can be considered another form of disagreement with government policies. Priest J. Williams read several sermons of this kind, in one of which he stated: "The sword of Christianity is a word of God and it will not admit of carnal warfare, either for its propagation of its defence"72.

Turning to the next designated period of intensification of activity of the Anglican clergy in the struggle for preservation of the ancien regime, it should be emphasized that many things in the late 1810s remained unchanged. Clerics of different ranks continued to teach submission and subordination based on the same texts of the Holy Scripture as before: Provebs 24:21-22; 1 Peter 2:17; Romans 13 1:4; 1 Timothy 2: 2; Titus 3:1. It is

${ }^{65}$ Cheap Repository Tracts; Entertaining, moral and religious. London, 1807. P. 4.

66 Ibid. P.7.

67 Ibid. P. 431.

68 See: e. g.: Murray N. U. The Influence of the French Revolution on the Church of England... P. 122.

${ }^{69}$ Paley W. Reasons for contentment. Addressed to the British public. Newcastle, 1819. P. 12.

70 See: e.g.: Gascoigne J. Anglican Latitudinarianism and Political Radicalism in the Late Eighteenth Century // History. 1986. Vol.71. P.22-38.

${ }_{71}$ The Works of Vicesimus Knox. 1824. Vol. 5. London. P. 186.

72 Williams J. War the Stumbling Block of a Christian; or, the Absurdity of Defending Religion by the Sword. London, 1795. P. 6. 
significant that in 1820 the abovementioned sermons by W. Jones and G. Horne, read in 1789, were republished being included in the collection entitled "Christian Politics". The editor of this book stressed the need for their publication "in these unquiet times"73.

Impressed by the crowded meetings, during which radical speakers put forward the requirements of universal suffrage and parliamentary reform, H. More prepared an expanded and modified edition of Cheap Repository Tracts, with the subtitle "suited to the present times". Lower orders were lucidly explained that in the case of "reforms" and "changes", "Britain a name now admird by the world // To the pit of destruction would quickly be hurl'd"74. The idea of undesirability of any changes in the Church of England was persistently pursued. The hero of one of the ballads, "the loyal subject", believes that the Church "wants attending" and absolutely does not need "mending"75.

The French Revolution continued to be seen as the source of all modern upheavals and misfortunes ${ }^{76}$ but the clergy now saw the main danger in the spread of "atheism" and "infidelity" in the country, noting with alarm the emergence of "blasphemous" and "seditious" publications $\mathrm{s}^{77}$. According to clerics, there was an inextricable connection between blasphemy and sedition. Bishop of Ely B. Sparke emphasized: "the transition from infidelity to disloyalty is but too easy; they who do not fear God will not long honour the King" ${ }^{\text {" }}$. Under these conditions, the bishop's most important task for the clergy was to fulfill its functions as "appointed guardians of religion, that bulwark of every state"79.

Recognizing the preservation of the apologetic tendency with regard to the ancien regime as the most important, it is necessary to note some changes in comparison with the 1790s. Firstly, the Anglican clergy found it necessary to respond to the changing face of the country that was a result of the rapid growth of the population and industry. In 18151817, two pamphlets of chaplain of Chelsea hospital R. Yates were published. The author, while continuing to develop traditional ideas about the priority of the protective function of the Church of England (the priests were called by him "preventive and corrective police" 80 , and the Church itself - the "best guardian of our civil as well as Ecclesiastical liberties"81), spoke in favor of building new churches in highly populated areas ${ }^{82}$. The Parliament supported his initiative, and in 1818 a considerable sum of $£ 1$ million was granted for the construction of new churches. Of course, this was a choice in favor of an extensive rather than intensive (implementation of inner-church reforms) development dictated by the desire to provide an opportunity for the population of industrial areas to receive "instructions", "upon which the very Existence of Religion, the Stability of the Church of England, and the security of the State do most essentially depend"83. However, the Church already acknowledged new realities, connected with industrialization.

73 Christian Politics. Oxford, 1820. P. 2.

74 More H. Cheap Repository Tracts, suited to the present times. London, 1819. P. 142.

75 Ibid. P. 144.

76 See, for example: Van Mildert W. An historical view of the rise and progress of infidelity. 1839. Vol. 1. Oxford. P.336-337.

77 See, for example: Sparke B. A Charge Delivered to the Clergy of the Diocese of Ely. London, 1817. P. 7; Howley W. A Charge delivered to the Clergy of the Diocese of London. London, 1818. P. 12-13.

${ }_{78}$ Sparke B. A Charge Delivered to the Clergy of the Diocese of Ely... P. 8.

79 Ibid. P.9.

80 Yates R. The Church in Danger. London, 1815. P. 132.

81 Ibid. P. 5.

82 Ibid. P. 126-128.

83 Ibid. P. 212; Yates R. The Basis of National Welfare. London, 1817. P. 44. 
Secondly, as E. Lyon notes, in spite of the publication of a significant number of sermons and charges, in which the idea of necessity of submission and contentment was repeated constantly, interest in literature of this kind decreased markedly ${ }^{84}$. An indirect confirmation of this thesis is the fact that at the end of the 1810s, the character and direction of the unrest had nothing in common with the actions of the loyalist "Church and King mobs" of the late $18^{\text {th }}$ century. Riots arose, as a rule, during mass meetings, the participants of which protested against the hard living conditions and economic distress and/or demanded electoral reform (the Spa Fields riots, 1816; Peterloo massacre, 1819). The emergence of such radical magazines as "The Black Dwarf", "Gorgon", which criticized the Church of England as the engine of the State and ruling oligarchy, also should be noted. In one of the issues of "The Black Dwarf", the clergy of the Established Church was condemned for the fact that it "preach blind submission and obedience... exhort people not to think for things are as well as they can be... censure reason as erring guide and politics as things with which poor men nothing to do" 85 . In the 1790 s, mass publications promoting such views were unthinkable.

Thirdly, the attitude towards nonconformists had seriously changed. Accusations of intentions to undermine the position of the Church of England against the dissenters were still aired ${ }^{86}$ but they were not considered already as a serious threat to the existing order. R. Yates regarded "liberty of conscience" as a measure that ensures social stability and strengthens the status of the Church of England, which, in his opinion, should be recognized by "judicious and liberal Dissenters" 87 . Bishop of Gloucester H. Ryder admitted, albeit with some reservations, the cooperation of Anglican priests and dissenting pastors within the framework of the Bible Society ${ }^{88}$.

Fourthly, there appeared some priests who were ready to criticize publicly the existing government accusing it of non-Christian behavior. Archdeacon of Norwich H. Bathurst condemned both the external (the imposition of Louis XVIII to the people of France) and the internal (restriction of press freedom) policy of the administration of Lord Liverpool in harsh expressions: "Terror, instead of reason and conciliation, is the sole instrument of the present Administration... Ministers, instead of any attempt to conciliate or reform, have... only procured laws to stop the mouths of opponents" 89 .

The fact of expressing such opinions publicly is unique, but not the fact of their existence among the clergy of the State Church. In 1825, the latitudinarian deacon T.Arnold, headmaster of a school in Laleham, in private correspondence called "destruction of the feudal tyranny of the nobility and great men" in France, a "blessing", enough to compensate "for the evils of the... Revolution" 90 . The scale of the spread of such views among the clergy should not be exaggerated, but the fact of their emergence can be carefully considered a symptom of the approaching changes.

The events of 1830-1832 were an ordeal for the Church of England. The Parliamentary reform was the final act of the Constitutional revolution of 1828-1832, which, accord-

${ }^{84}$ Lyon E. Politicians in the Pulpit: Christian Radicalism in Britain from the Fall of the Bastille to the Disintegration of Chartism. London, 1999. P. 58-59.

85 "The Black Dwarf". 21.04.1819.

${ }^{86}$ See, for example: Howley W. A Charge delivered to the Clergy of the Diocese of London... P. 13-14.

87 Yates $R$. The Basis of National Welfare... P. 170-171.

${ }^{88}$ Ryder H. A Charge delivered to the clergy of the Diocese of Gloucester. Gloucester, 1816. P. 30-33.

89 Bathurst H. Christianity and Present Politics. London, 1818. P. 63.

90 Stanley A. P. The Life and Correspondence of Thomas Arnold. Vol. 1. Boston, 1862. P. 81. 
ing to the words of the author of this term, the British historian G. Best, led to the transformation of an "an aristocratic semi-confessional state... to that of a semi-democratic liberal state" 91 . The Anglican episcopate was so closely associated with the ancien regime that it opposed Parliamentary reform more strongly than the first two acts of the Constitutional revolution - repeal of the Test and Corporation Acts (1828) and the Roman Catholic Emancipation (1829). These reforms undermined the constitutional monopoly of the Church of England, and so affected it directly, while the changing of the system of parliamentary representation - only indirectly. The first bill, expanding the political and civil rights of dissenters, was approved by the House of Lords even without separation. This clearly showed that times had changed and nonconformists were no longer perceived as a political threat, even by bishops. The Catholic Emancipation bill at the last stage was supported by 8 bishops (previously only 2 ), and 16 were against it.

When the Parliamentary reform bill, approved in the lower House, was put to a vote at the House of Lords (October 7, 1831), the overwhelming majority of the Anglican prelates (21 out of 23) cast their vote for its rejection. Since the Reform Bill was rejected by a majority of 41 votes, a significant part of the reformist-minded English public laid the main blame for the failure of the bill on the prelates. In October-November 1831, a largescale outbreak of anti-clericalism followed, which England had not seen before. Images of bishops were burned; on the streets they were attacked by mobs; windows were being broken in the houses of priests. In Bristol, the Episcopal Palace was burned on October 29-30. If the riots of the late 1810s were different from the actions of the "Church and King mobs", the events of October-November 1831 were already complete opposite to them. The Church of England became an incredibly unpopular institution. "If we except the period which preceded the Church's overthrow in the time of Charles I, there never was a time when the clergy were assailed with so much calumny and so much violence as they are at present", - wrote Bishop of Peterborough H. Marsh ${ }^{92}$.

The events of October - November 1831 made a strong impression on many prelates. As a result, during the discussion of the new version of the Reform Bill on April 13, 1832, 12 Anglican bishops voted "for", whereas 15 were against. Proponents of the bill (for example, Bishop of London C. Blomfield) described it as a measure that could "improve the Representation, conciliate the affections of the people"93. Opponents of the reform, however, continued to defend the ancien regime by arguments that already became classical. Bishop of Durham W. Van Mildert complained of too active dissemination of knowledge among the lower classes leading to the desire "to destroy institutions because they were ancient, - a desire to set subject over the ruler, and to trample ruler under the subject"94. Bishop of Rochester G. Murray urged legislators not to yield to "mob clamour", stressing that "the lower classes should not be called into council; they should not be suffered to interfere with matters connected with legislation" 95 .

The lower clergy reasoned similarly. A modern scholar R. Saunders quotes sermons of priests who belonged to different Anglican parties, in which campaign for the reform

91 Best $G$. The Constitutional Revolution, 1828-1832, and its consequences for the Established Church // Theology. 1959. Vol. 62. P. 229.

${ }_{92}$ Marsh H. A Charge, delivered to the Clergy of the Diocese of Peterborough, in July, 1831. London, 1831. P.7.

${ }_{93}$ Hansard's Parliamentary Debates. 1832. Vol. 12. London. P. 271.

94 Ibid. P. 50.

95 Ibid. P. 401. 
was called "a rebellion against God", destroying the principle of obedience to a superior power ${ }^{96}$. The future leader of the Oxford movement in the Church of England, and at that moment - a priest and fellow of the Oxford University, J.H. Newman, called "development (as it is called) of the popular power" as sinful as the actions of the invaders since God "forbids us to oppose constituted power" 97 . However, now among the clergy an influential minority emerged, not only thinking differently but also speaking in support of Parliamentary reform. If we talk about personalities, it is a prebendary of Durham T. Gisborne; H. Price, curate of Christ Church, Nedwood, who was involved in a dispute between the manufacturers and weavers on the side of the latter in the 1820s and received a prison sentence for distributing ballads recognized as libellous; A. Wade, vicar of St. Nicholas; Warwick, who took an active part in the work of the Birmingham Political Union - the largest reform community. The activity of these persons was discussed in details in the monograph of E. Lyon ${ }^{98}$. To this group can also be added: a liberal priest S. Smith, who spoke at meetings about the need for urgent correction of the decayed political institutions ${ }^{99}$, as well as T. Arnold, who had become a priest by that time, although he expressed support for the reform with great caution, objecting to its consideration as a panacea for all ills ${ }^{100}$.

It is possible to make a conclusion about how numerous the reformists were and? the supporters of political transformations among the clergy, using statistical data on the votes of Anglican priests at the parliamentary elections, which were held thrice in 18301832. These data are fragmentary as they cover only 18 electoral districts out of about 500, where elections were actually held, and reproduce the results of one or two electoral campaigns. Avoiding the exact figures, because in some cases dissenting pastors might have been included in the category of "clergy", the following can be stated. For candidates from the Tory party, who opposed the Reform Bill, about 1,100 votes were cast by clergymen of the Church of England, and about 400 for the Whigs ${ }^{101}$. In percentage terms, it looks like $73 \%$ versus $27 \%$. All these data can serve as confirmation of the conclusion that anti-reform views prevailed over pro-reform positions in the clerical environment, but not as the exclusiveness of the latter.

\section{Conclusion}

The feeling of the imminent collapse of the Church of England, at least as a state institution, was was very widespread. Historians often cite the following phrase from the letter of T. Arnold (1832): "The Church, as it now stands, no human power can save"102. This, as we know, did not happen, and for many reasons. Among the most important are the absence of any desire from the side of Whig party to move along this path, preferring the careful implementation of the internal reform of the Church of England with the aim

96 Saunders R. God and the Great Reform Act: Preaching against Reform, 1831-32 // Journal of British Studies. 2014. Vol. 53. P. 391-394.

97 Newman J.H. Sermons, Chiefly on the Theory of Religious Belief, Preached before the University of Oxford. London, 1844. P. 140.

${ }^{98}$ Lyon E. Politicians in the Pulpit... P. 87-88, 101-111.

99 The Works of the Rev. Sydney Smith. 1840. Vol. 4. London. P. 376-385, 392-411.

100 The Miscellaneous Works of Thomas Arnold. New York, 1846. P. 413.

101 Vincent J.R. Pollbooks: How Victorians Voted. Cambridge, 1967.

102 Stanley A.P. The Life and Correspondence of Thomas Arnold. Vol. 1. P. 283. 
of increasing its effectiveness, as well as the understanding of the need for serious changes that had matured in the church environment itself. "The people must be gained or all is lost", emotionally noted in 1833 the Church magazine "The British Critic"103. Ways of gaining confidence were various. The Oxford movement, which started in 1833, focused on the restoration and development of the sacral potential of Anglicanism, and had a huge impact on its further development ${ }^{104}$. Although J. H. Newman largely retained his paternalistic convictions, he did not consider that the apology of the existing order was the prime task of the Church: "The Gospel then has come to us not merely to make us good subjects, good citizens, good members of society, but to make us members of the New Jerusalem", and "fellow citizens with the saints and of the household of God"105.

Another part of the clergy, headed by Bishop Blomfield, pursued, in collaboration with the Whig and Tory governments, internal Church reforms aimed at increasing its efficiency. R. Saunders points out that in discussions about the second (1867) and the third (1884-1885) reforms of Parliament, mostly utilitarian arguments were made, and, unlike in the early 1830s, "no special role was asserted for government itself as a religious agent" 106 . Nevertheless, as G. Kitson Clark showed, the sermons, in which an unequal order of society was represented as God-given, continued to sound after $1832^{107}$. This is hardly surprising since the process of disappearance of the English ancien regime was rather slow and gradual, as in some other European countries ${ }^{108}$. But from the 1830 s the clergy, including the episcopate, began to show an increasing interest in solving social problems, and the themes of submission and subordination ceased to act as central.

\section{References}

Bancroft T. A Sermon preached at the Cathedral church, in Chester. Manchester, Harrop, 1793, 15 p.

Baryshnikov V.N., Borisenko V.N., Stetckevich M.S. The Oxford Movement and the English Reformation. Vestnik of Saint Petersburg University. History, 2017, vol. 62, no. 4, pp. 826-838.

Bathurst H. Christianity and Present Politics. London, Printed for J. Ridgway, 1818, 72 p.

Bayley C. Religion and Loyalty inseparable. Manchester, [S. n.], 1792, 24 p.

Best G. F. A. Temporal Pillars. Queen Anne's Bounty, the Ecclesiastical Commissioners and the Church of England. Cambridge, Cambridge University Press, 1964, 600 p.

Best G. The Constitutional Revolution, 1828-1832, and its consequences for the Established Church. Theology, 1959, vol. 62, no. 468, pp. 226-234.

Black J. England's Ancien Regime? History Today, 1988, vol.38, no. 3, pp. 43-51.

Clark J.C.D. English Society, 1688-1832. Ideology, Social Structure and Political Practice during the Ancien Regime. Cambridge, Cambridge University Press, 1985, 449 p.

Clark J. C. D. English Society, 1660-1832: Religion, Ideology, and Politics during the Ancien Regime. Cambridge, Cambridge University Press, 2000, 596 p.

Cockburn H. Memorials of His Time. New York, D. Appleton and Company, 1856, 442 p.

Cookson J. E. Lord Liverpool's administration: The crucial years, 1815-1822. London: distributed by Chatto and Windus, 1975, $422 \mathrm{p}$.

Evans E. J. Some Reasons for the Growth of English Rural Anti-clericalism. Past \& Present, 1975, no. 66, pp. 84-109.

103 The British Critic. 1833. Vol. 14, No. 28. P. 453.

104 See e.g.: Baryshnikov V.N., Borisenko V.N., Stetckevich M.S. The Oxford movement and the

English reformation // Vestnik of Saint Petersburg University. History. 2017. Vol. 62, iss. 4. P. 826-838.

105 Newman J. H. Parochial Sermons. Vol. 4. London, 1849. P. 183.

106 Saunders R. God and the Great Reform Act... P. 399.

107 Kitson Clark G. Churchmen and Condition of England... P.9-11.

108 Plenkov O.Y., Baryshnikov V.N., Borisenko V.N., Piankewich V.L., Adamova N.E. Prussian phenomenon and its historical distortion // Bylye gody. 2016. Vol. 39, no. 1. P. 196-203. 
Gascoigne J. Anglican Latitudinarianism and Political Radicalism in the Late Eighteenth Century. History, 1986, vol. 71, no. 231, pp. 22-38.

Gilbert A. D. Religion and Society in Industrial England: Church, Chapel and Social Change, 1740-1914. London, Longman, 1976, $251 \mathrm{p}$.

Hilton B. Corn, Cash, Commerce: Economic Policies of the Tory Governments, 1815-30. Oxford, University Press, 1980, $320 \mathrm{p}$.

Hole R. Pulpits, Politics and Public Order in England, 1760-1832.Cambridge, Cambridge University Press, 1989, $344 \mathrm{p}$.

Horsley S. A Sermon Preached before the Lords Spiritual and Temporal on January 30, 1793. London, Printed for J. Robson, 1793, $39 \mathrm{p}$.

Howley W. A Charge delivered to the Clergy of the Diocese of London. London, Longman, 1818, $28 \mathrm{p}$.

Huntingford G. Twelve Discourses on Different Subjects. London, Printed for T. Cadell, 1795, 338 p.

Innes J. Jonathan Clark, Social History and England's "Ancien Regime". Past \& Present, 1987, no. 115, pp. 165-200.

Jacob W. M. The Clerical Profession in the Long Eighteenth Century, 1680-1840. Oxford, Oxford University Press, 2007, 366 p.

Jones W. Sermons: Practical, Doctrinal and Expository. London, Printed and Published by J.F. Dove, 1829, $600 \mathrm{p}$.

Kitson Clark G. Churchmen and Condition of England, 1832-1885. A Study in the Development of Social Ideas and Practice from the Old Regime to the Modern State. London, Methuen, 1973, $373 \mathrm{p}$.

Koabel G. Religious loyalism: The Anglican Church and the conservative movement of 1792-3. A Thesis for the degree of Master of Arts in History, Regina, [S.n.], 2009, 108 p.

Lyon E. Politicians in the Pulpit: Christian Radicalism in Britain from the Fall of the Bastille to the Disintegration of Chartism. London, Routledge, 1999, $280 \mathrm{p}$.

MacLeod E. British Attitudes to the French Revolution. The Historical Journal, 2007, vol. 50, no. 3, pp. 689709.

Manners-Sutton C. A Sermon Preached before the Lords Spiritual and Temporal on Friday, February $28^{\text {th }}$, 1794. London, Printed for J. Robson, 1794, 22 p.

Marsh H. A Charge, delivered to the Clergy of the Diocese of Peterborough, in July, 1831. London, Rivingtons, $1831,14 \mathrm{p}$.

More H. Cheap Repository Tracts, suited to the present times. London, Printed for F. C. and J. Rivington, 1819, $160 \mathrm{p}$.

Murray N. U. The Influence of the French Revolution on the Church of England and its Rivals. Ph.D. Thesis. Oxford, [S.n.], 1975, 397 p.

Newman J.H. Sermons, Chiefly on the Theory of Religious Belief, Preached before the University of Oxford. London, Francis and John Rivington, 1844, 354 p.

Newman J. H. Parochial Sermons. Vol. 4. London, James Burns, 1849, 389 p.

O'Gorman F. The Long Eighteenth Century: British Political and Social History 1688-1832. London, Bloomsbury, 2016, $457 \mathrm{p}$.

Paley W. Reasons for contentment. Addressed to the laboring part of the British public. Newcastle, Printed by E. Walker, $1819,12 \mathrm{p}$.

Plenkov O. Y., Baryshnikov V.N., Borisenko V.N., Piankewich V.L., Adamova N.E. Prussian phenomenon and its historical distortion. Bylye gody, 2016, vol.39, no. 1, pp. 196-203. (In Russian)

Porter R. Georgian Britain: an Ancien Regime? British Journal for Eighteenth Century Studies, 1992, vol. 15, pp. 141-144.

Porter R. Enlightenment. Britain and Creation of the Modern World. London, Penguin, 2001, 752 p.

Pretyman-Tomline G. A Charge Delivered to the Clergy of the Diocese of Lincoln in May and June 1794. London, Printed for R. Faulder, 1794, 25 p.

Ravitch N. The Social Origins of French and English Bishops in the Eighteenth Century. The Historical Journal, 1965, vol. 8, no. 3, pp. 309-325.

Rose R. B. The Priestley Riots of 1791. Past and Present, 1960, no. 18, pp. 68-88.

Rosen M. The Dictatorship of the Bourgeoisie: England, 1688-1721. Science \& Society, 1981, vol.45, no. 1, pp. 24-51.

Russell A. The Clerical Profession. London, Abingdon Press, 1989, 368 p.

Ryder H. A Charge Delivered to the Clergy of the Diocese of Gloucester. Gloucester, Printered by Walker and Sons, $1816,35 \mathrm{p}$.

Saunders R. God and the Great Reform Act: Preaching against Reform, 1831-32. Journal of British Studies, 2014, vol.53, pp. 378-399. 
Soloway R. A. Prelates and People. Ecclesiastical Social Thought in England, 1783-1852. London, Routledge, $1969,480 \mathrm{p}$.

Sparke B. A Charge Delivered to the Clergy of the Diocese of Ely. London, Rivingtons, 1817, 24 p.

Stanley A. P. The Life and Correspondence of Thomas Arnold. Vol. 1. Boston, Ticknor and Fields, 1862, 378 p.

Tatham E. A Sermon Suitable to the Times. London, Rivington, 1792, 19 p.

Van Mildert W. An historical view of the rise and progress of infidelity. Vol. 1. Oxford, Printed by T.Combe, $1839,466 \mathrm{p}$.

Vincent J. R. Pollbooks: How Victorians Voted. Cambridge, University Press, 1967, 206 p.

Watson R. Miscellaneous Tracts on Religious, Political and Agricultural Subjects. Vol.2. London, Printed by Luke Hansard and Sons, 1815, 439 p.

Watts M.R. The Dissenters. From the Reformation to the French revolution. Oxford, Clarendon Press, 1978, $561 \mathrm{p}$.

Wilberforce W. A Practical View of the Prevailing Religious Systems of Professed Christians in the Higher and Middle Classes of this Country Contrasted with Real Christianity. London, Printed for T. Cadell, 1797, $491 \mathrm{p}$.

Will Chip [More H.]. Village Politics. York, Printed and sold by G. Walker, 1793, 18 p.

Williams J. War the Stumbling-Block of a Christian; Or, the Absurdity of Defending Religion by the Sword. London, Printed for T. Cadell, 1795, 34 p.

Yates R. The Basis of National Welfare. London, F. C. and J. Rivington, 1817, 374 p.

Yates R. The Church in Danger. London, Printed by Nichols, Son, and Bentley, 1815, 226 p.

Received: April 19, 2019

Accepted: September 9, 2019

Статья поступила в редакцию 19 апреля 2019 г.

Рекомендована в печать 9 сентября 2019 г. 